\title{
GLYCEMIC STATUS AS A PREDICTOR FOR THE OUTCOMES IN PATIENTS WITH ACUTE ORGANOPHOSPHORUS PESTICIDES POISONING
}

\author{
Ghada A. Sagah \& Amira E. Elhawary \\ Forensic Medicine and Clinical Toxicology- Faculty of Medicine - Tanta University- Tanta- \\ Egypt \\ Corresponding author: Ghada A. Sagah \\ Email : ghadaattia@med.tanta.edu.eg \\ Mobile: 01003642188 \\ Date of submission: 2 October 2020 \\ Revised at: 5 January 2021 \\ Accepted at: 11 January 2021
}

\begin{abstract}
Background: Acute organophosphate (OP) toxicity is a major health problem in different populations. Nearly three million cases are affected annually all over the world. The most common clinical presentations include muscarinic, nicotinic, and central nervous system manifestations resulting from cholinergic overload. Nevertheless, endocrine toxicity and affection of glucose homeostasis are reported. Objectives: The current study aimed to study random blood sugar (RBS) as a simple, inexpensive tool to predict mortality and major outcome events in acute organophosphate poisonings. Patients \& methods: Ninety adult patients with acute organophosphate poisoning were included in the study. Patients already known to be diabetic before exposure and those with mixed intoxication were excluded. RBS was done to all included patients on admission before receiving any medications. Results: Patients were categorized into euglycemic (62.2\%), hyperglycemic (28.9\%), and hypoglycemic $(8.9 \%)$. The severity of organophosphorus poisoning symptoms and signs was graded into; Mild (32.2\%), Moderate (38.9\%), and Severe $(28.9 \%)$ grades with a statistically significant association between RBS and poisoning severity at the time of admission. In addition, RBS showed a statistically significant association with each of serum cholinesterase levels, the delay time before hospital admission, the need for intubation, mechanical ventilation, and death. Meanwhile, RBS had no statistically significant association with either dose of atropine \& toxogonine or the duration of hospital stay. Conclusion: It could be concluded that random blood sugar on admission in acute organophosphorus poisoned patients is a simple, cheap, and reliable marker that may help to predict the clinical severity and outcomes.
\end{abstract}

Keywords: Acute Organophosphate Toxicity, random blood sugar (RBS), Ventilation, Mortality.

\section{INTRODUCTION}

Organophosphates are esters of phosphoric acid designed for pest control both in agriculture and household gardens (Kharel et al., 2020). Globally, these heterogeneous compounds constitute a common accidental health hazard. Easy availability and low cost make them one of the most commonly used suicidal poisons, especially in developing countries (Afify et al., 2016a; Dungdung et al., 2020). Worldwide, acute organophosphorus pesticide poisoning registered a high prevalence, affecting about 3 million people, with 300000 deaths annually (Geetha Rani et al., 2020).

Organophosphate toxicity is mediated through covalent phosphate binding to cholinesterase's active sites rendering them enzymatically inert (Afify et al., 2016b; Oliveira et al., 2019). Afterward, initial overstimulation of the central nervous system, cholinergic synapses, together with neuromuscular junctions, takes place. This 
is followed by central and peripheral paralysis. Subsequently, Muscarinic, nicotinic, and central nervous system manifestations will result from cholinergic overload (Elagamy \& Gabr, 2019).

In addition, organophosphate induces disruption of cellular oxidative balance, immunotoxicity, reproductive toxicity, and genotoxicity. Furthermore, endocrine toxicity and glucose homeostasis are affected (Raveendra et al., 2020). Moreover, a variety of glycemic states ranging from hypoglycemia to hyperglycemia, and rarely ketoacidosis can be reported (Kurtoglu, 2019).

In animal studies, Panda et al. (2015) have registered increased cholinergic activities due to hyperglycemia, together with hyperglycemic changes during anticholinesterase poisoning. In human research, Raghapriya et al., 2018 suggested an association between glycemic state and morbidity, mortality, and mechanical ventilation assistance.

Predicting outcome in critically ill patients is a key component and a major concern in any health care system. At the same time, acute organophosphate toxicity still a big problem with major consequences, together with a striking lack of recent Egyptian studies regarding random blood sugar (RBS) as a predictor of acute organophosphate toxicity. Hereafter, the current study aimed to use RBS as a simple, inexpensive tool to predict mortality and major outcome events in acute organophosphate poisonings.

\section{PATIENTS AND METHODS}

This study is a prospective crosssectional study. It was carried out following the approval of the medical research ethical committee of Tanta Faculty of Medicine on patients admitted to Tanta Poison Control Center, Tanta Emergency University Hospital with acute organophosphorus poisoning throughout the period from the $1^{\text {st }}$ of September 2019 to the 31st of August 2020.
All included patients or guardians (if the patients were unable to participate in the consent process) were asked to provide informed written consent for participation after receiving detailed information about the study. Data confidentiality, including the results of investigations, was maintained by making code numbers for every patient (available for main investigator only), data were analyzed anonymously.

Adult patients acutely exposed to organophosphate were included in the study. Patients who were known to be diabetic before exposure or with abnormal $\mathrm{Hb}$ and/or $\mathrm{Hb} \mathrm{A} 1 \mathrm{c}$ levels were excluded. Moreover, patients with chronic renal disease, chronic pancreatic disease, chronic liver disease, alcoholics, and pregnant females were excluded. Additionally, patients admitted with mixed intoxication or associated trauma, and those who received any medications before admission were excluded from the study.

Diagnosis of organophosphorus poisoning was based on the history of exposure, the presence of organophosphorus symptoms and signs, clinical improvement after administration of atropine and oximes (toxogonin), and the decrease in serum cholinesterase enzyme levels (Tsai et al., 2007 and ElEbiary et al., 2016).

Demographic data (including age, gender, occupation, and residence) and Toxicological data (including the route of exposure and manner of poisoning) were reported for all included cases.

The severity of symptoms and signs of acute OPP was graded according to Minton \& Murray (1988) into Mild OPP; headache, blurred vision, dizziness, fatigue, nausea, vomiting, excessive sweating, salivation, abdominal pain, and tightness in the chest. Moderate OPP; Symptoms of mild poisoning in addition to muscular fasciculation, weakness, inability to walk, chest crepitations, and miosis. Severe OPP; Symptoms of moderate poisoning in addition to unconsciousness, 
flaccid paralysis, respiratory distress, cyanosis, and marked miosis with loss of pupil reflexes.

Blood samples were collected at the time of admission before administrating any medication under complete aseptic conditions. Two milliliters of venous blood were kept into a clean, dry tube and left standing for a few hours before centrifugation to avoid hemolysis. Serum was separated and then used to estimate both serum cholinesterase level and random blood glucose.

Serum cholinesterase level was measured using butyrylthiocholine substrate, commercial kit supplied by Biodiagnostic, Egypt (normal value 540013200 U/L) (Kende and Bottger 1967;

Blawen et al., 1983). Random blood sugar level was determined according to Trinder (1969) and Sharp (1972) by glucose oxidase method. Blood collection syringes, tubes, and body fluids (blood samples) were safely disposed of for infection control and to avoid any risk of environmental pollution.

Based on RBS levels at the time of admission, patients were categorized into three groups; hypoglycemic with RBS less than $70 \mathrm{mg} / \mathrm{dL}$, euglycemic (70-140 $\mathrm{mg} / \mathrm{dL}$ ), and hyperglycemic with RBS exceeding $140 \mathrm{mg} / \mathrm{dL}$ (Raveendra et al., 2020).

Statistical analysis was performed using Statistical Package for Social Sciences (IBM SPSS Statistics) for Windows, version 26 (IBM Corp., Armonk, NY, USA). For quantitative data, assessment of distribution was performed using the Shapiro-Wilk test for normality and visual assessment of graphs.

For normally distributed data, variables were summarized as mean \pm standard deviation (SD). Comparison between the three studied groups was carried out using the One-way ANOVA test (followed by Tukey posthoc test if ANOVA yielded significant $p$-value).

For abnormally distributed data, the variables were summarized as the median and interquartile range (IQR, expressed as $25^{\text {th }}-75^{\text {th }}$ percentiles). Comparison between the three studied groups was carried out using Kruskal-Wallis (KW) test (followed by Dunn-Bonferroni posthoc test if $\mathrm{KW}$ yielded a significant $\mathrm{p}$-value).

Correlation between numerical variables was studied using Spearman's rank-order correlation. Spearman's correlation coefficient $\left(\mathrm{r}_{\mathrm{s}}\right)$ measured the direction and strength of the correlation. A coefficient $\leq 0.39$ is considered weak, 0.40 - 0.96 is moderate, and $\geq 0.7$ is strong (Schober et al., 2018). A p-value $\leq 0.05$ was adopted for interpretation of statistical tests.

\section{RESULTS}

During the study period, 90 patients presenting with acute organophosphorus poisoning fulfilled the inclusion and exclusion criteria. The mean age of included patients was $36.1 \pm 13.2$, with a predominance of males $(81.1 \%)$. Sociodemographic characteristics of participant patients are illustrated in table (1).

Table (2) demonstrates the toxicological and clinical data of studied patients. Patients were categorized into euglycemic (62.2\%), hyperglycemic (28.9\%), and hypoglycemic (8.9\%). Eighty patients $(88.9 \%)$ were improved and discharged; meanwhile, ten patients ended up with death. Intubation and mechanical ventilation were required in $13.3 \%$ of included patients.

Sociodemographic data, route, and manner of poisoning registered no significant association with random blood sugar on admission. Meanwhile, delay time before hospital admission revealed a significant association with random blood sugar on admission (Table 3). Furthermore, Spearman's rank-order correlation showed that there was a significant positive correlation between random blood sugar and delay time before hospital admission $\left(r_{s}=0.220, p=0.037\right)$.

On admission, both severities of poisoning and serum cholinesterase levels 
had a significant association with RBS (Table 4). Spearman's rank-order correlation declared that there was a significant positive correlation between random blood sugar and severity of poisoning $\quad\left(\mathrm{r}_{\mathrm{s}}=0.385, \quad \mathrm{p}<0.001\right) . \quad \mathrm{A}$ significant negative correlation existed between random blood sugar and serum cholinesterase level $\left(r_{s}=-0.337, p=0.001\right)$.
Table (4) illustrates that RBS had no significant association with atropine \& toxogonin doses and duration of hospital stay. On the other hand, there was a significant association between RBS and both need for mechanical ventilation and death.

Table (1): Sociodemographic data of organophosphate poisoned patients $(\mathrm{N}=90)$

\begin{tabular}{|c|c|c|c|c|c|c|c|c|c|c|c|}
\hline \multicolumn{4}{|c|}{ Age } & \multicolumn{4}{|c|}{ Gender } & \multicolumn{4}{|c|}{ Residence } \\
\hline \multirow{2}{*}{ Min. } & \multirow{2}{*}{ Max. } & \multirow[b]{2}{*}{ St.dev. } & \multirow[b]{2}{*}{ Mean } & \multicolumn{2}{|c|}{ Male } & \multicolumn{2}{|c|}{ Female } & \multicolumn{2}{|c|}{ Urban } & \multicolumn{2}{|c|}{ Rural } \\
\hline & & & & N. & $\%$ & $\mathrm{~N}$. & $\%$ & $\mathrm{~N}$. & $\%$ & N. & $\%$ \\
\hline 18.0 & 65.0 & 13.2 & 36.1 & 73 & $81.1 \%$ & 17 & $18.9 \%$ & 25 & $27.8 \%$ & 65 & $72.2 \%$ \\
\hline \multicolumn{12}{|c|}{ Occupation } \\
\hline \multicolumn{6}{|c|}{ Employed } & \multicolumn{6}{|c|}{ Unemployed } \\
\hline \multicolumn{2}{|c|}{ Employed } & \multicolumn{2}{|c|}{ Farmer } & \multicolumn{2}{|c|}{$\begin{array}{l}\text { Skilled } \\
\text { worker }\end{array}$} & \multicolumn{2}{|c|}{ Housewife } & \multicolumn{2}{|c|}{ unemployed } & \multicolumn{2}{|c|}{ Student } \\
\hline N. & $\%$ & $\mathrm{~N}$. & $\%$ & N. & $\%$ & N. & $\%$ & N. & $\%$ & N. & $\%$ \\
\hline 7 & $7.8 \%$ & 52 & $57.8 \%$ & 7 & $7.8 \%$ & 11 & $12.2 \%$ & 7 & $7.8 \%$ & 6 & $6.7 \%$ \\
\hline
\end{tabular}

N: number - Min: minimum - Max: maximum - St.dev: standard deviation.

Table (2): Toxicological and clinical data of organophosphate poisoned patients $(\mathrm{N}=90)$

\begin{tabular}{|c|c|c|c|c|c|c|c|c|c|c|c|}
\hline \multicolumn{4}{|c|}{ Manner of poisoning } & \multicolumn{4}{|c|}{ Pre-hospitalization period (hours) } & \multicolumn{4}{|c|}{ Route of poisoning } \\
\hline \multicolumn{2}{|c|}{ Accidental } & \multicolumn{2}{|c|}{ Suicidal } & \multirow[t]{2}{*}{ Min } & \multirow[t]{2}{*}{ Max. } & \multirow[t]{2}{*}{ Median } & \multirow[t]{2}{*}{ IQR } & \multicolumn{2}{|c|}{ Ingestion } & \multicolumn{2}{|c|}{ Combined } \\
\hline No. & $\%$ & No. & $\%$ & & & & & No. & $\%$ & No. & $\%$ \\
\hline 56 & $62.2 \%$ & 34 & $37.8 \%$ & 1.0 & 24.0 & 4.0 & $2.0-8.0$ & 38 & $42.2 \%$ & 52 & $57.8 \%$ \\
\hline \multicolumn{6}{|c|}{ Organophosphorus poisoning severity } & \multicolumn{6}{|c|}{ Cholinesterase level } \\
\hline \multicolumn{2}{|c|}{ Mild } & \multicolumn{2}{|c|}{ Moderate } & \multicolumn{2}{|c|}{ Severe } & \multirow[t]{2}{*}{ Min. } & \multirow[t]{2}{*}{ Max. } & \multirow{2}{*}{\multicolumn{2}{|c|}{ Median }} & \multirow{2}{*}{\multicolumn{2}{|c|}{ IQR }} \\
\hline No. & $\%$ & No & $\%$ & No. & $\%$ & & & & & & \\
\hline 29 & $32.2 \%$ & 35 & $38.9 \%$ & 26 & $\begin{array}{c}28.9 \\
\%\end{array}$ & 89.0 & 11485.0 & \multicolumn{2}{|r|}{2411.0} & \multicolumn{2}{|c|}{$\begin{array}{c}1161.0- \\
3480.0\end{array}$} \\
\hline \multicolumn{6}{|c|}{ Number of Atropine ampoules } & \multicolumn{6}{|c|}{ Number of Toxogonin ampoules } \\
\hline \multicolumn{2}{|l|}{ Min. } & Max. & Median & \multicolumn{2}{|c|}{ IQR } & Min. & Max. & \multicolumn{2}{|c|}{ Median } & \multicolumn{2}{|c|}{ IQR } \\
\hline 1.0 & & 8.0 & 10.0 & & -13.0 & 1.0 & 28.0 & & 4.0 & & -7.0 \\
\hline & & od of & spital st & & & & Rando & m blo & d sugar & & \\
\hline Min. & & ax. & Medial & & IQR & & mal & Нyp & $\begin{array}{l}\text { glycemi } \\
\text { c }\end{array}$ & Hype & $\begin{array}{l}\text { rglycem } \\
\text { ic }\end{array}$ \\
\hline 0.25 & & 0.0 & 2.0 & & $0-3.0$ & No. & $\%$ & No. & $\%$ & No. & $\%$ \\
\hline & & & & & & 56 & $62.2 \%$ & 8 & $8.9 \%$ & 26 & $28.9 \%$ \\
\hline & & & & & & tcome & & & & & \\
\hline $\operatorname{Imp}$ & broved & disch & ged & Intubs & tion \& & lechanical & entilation & & Mo & ality & \\
\hline $\mathrm{N}$ & & & $b$ & & Jo. & & $\%$ & & & q & \\
\hline 8( & 0 & & $9 \%$ & & 12 & & $3 \%$ & & & 11. & \\
\hline
\end{tabular}

N: number - Min: minimum - Max: maximum - IQR: Interquartile range 
Table (3): Comparison between groups of RBS status as regards relevant sociodemographic and toxicological data $(\mathrm{N}=90)$

\begin{tabular}{|c|c|c|c|c|c|c|c|c|c|c|c|}
\hline & \multicolumn{2}{|c|}{ Euglycemia } & \multicolumn{2}{|c|}{$\begin{array}{l}\text { Hyper- } \\
\text { glycemia }\end{array}$} & \multicolumn{2}{|c|}{$\begin{array}{l}\text { Hypo- } \\
\text { glycemia }\end{array}$} & \multicolumn{2}{|c|}{ Total } & \multirow{2}{*}{$\begin{array}{l}\text { Test } \\
\text { statistic } \\
2.623^{a}\end{array}$} & \multirow{2}{*}{$\begin{array}{l}\mathrm{p} \\
0.078\end{array}$} \\
\hline Age (years) & $\begin{array}{c}\text { Range } \\
\text { Mean } \pm \text { SD }\end{array}$ & \multicolumn{2}{|c|}{$\begin{array}{l}18-65 \\
35.3 \pm 12.9\end{array}$} & \multicolumn{2}{|c|}{$\begin{array}{l}18-60 \\
40.2 \pm 13.9\end{array}$} & \multicolumn{2}{|c|}{$\begin{array}{l}19-45 \\
28.9 \pm 10.9\end{array}$} & \multicolumn{2}{|c|}{$\begin{array}{l}18-65 \\
36.1 \pm 13.2\end{array}$} & & \\
\hline \multirow{2}{*}{ Gender } & Female & 8 & $47.1 \%$ & 6 & $35.3 \%$ & 3 & $17.6 \%$ & 17 & $100 \%$ & \multirow[t]{2}{*}{$3.078^{\mathrm{b}}$} & \multirow{2}{*}{0.213} \\
\hline & Male & 48 & $65.8 \%$ & 20 & $27.4 \%$ & 5 & $6.8 \%$ & 73 & $100 \%$ & & \\
\hline \multirow[t]{2}{*}{ Residence } & Urban & 4 & $16.0 \%$ & 17 & $68.0 \%$ & 4 & $16.0 \%$ & 25 & $100 \%$ & \multirow[t]{2}{*}{$4.133^{b}$} & \multirow[t]{2}{*}{0.125} \\
\hline & Rural & 4 & $6.2 \%$ & 39 & $60.0 \%$ & 22 & $33.8 \%$ & 65 & $100 \%$ & & \\
\hline \multirow[t]{2}{*}{ Occupation } & Employed & 4 & $6.1 \%$ & 44 & $66.7 \%$ & 18 & $27.3 \%$ & 66 & $100 \%$ & \multirow[t]{2}{*}{$3.279^{b}$} & \multirow[t]{2}{*}{0.185} \\
\hline & Unemployed & 4 & $16.7 \%$ & 12 & $50.0 \%$ & 8 & $33.3 \%$ & 24 & $100 \%$ & & \\
\hline \multirow{2}{*}{$\begin{array}{l}\text { Manner of } \\
\text { poisoning }\end{array}$} & Accidental & 39 & $69.6 \%$ & 13 & $23.2 \%$ & 4 & $7.1 \%$ & 56 & $100 \%$ & \multirow[t]{2}{*}{$3.551^{\mathrm{b}}$} & \multirow[t]{2}{*}{0.171} \\
\hline & Suicidal & 17 & $50.0 \%$ & 13 & $38.2 \%$ & 4 & $11.8 \%$ & 34 & $100 \%$ & & \\
\hline \multirow{2}{*}{$\begin{array}{l}\text { Route of } \\
\text { poisoning }\end{array}$} & Ingestion & 4 & $10.5 \%$ & 21 & $55.3 \%$ & 13 & $34.2 \%$ & 38 & $100 \%$ & \multirow[t]{2}{*}{$1.445^{b}$} & \multirow[t]{2}{*}{0.516} \\
\hline & Combined & 4 & $7.7 \%$ & 35 & $67.3 \%$ & 13 & $25.0 \%$ & 52 & $100 \%$ & & \\
\hline \begin{tabular}{|c|} 
Delay time before \\
hospital admission \\
(hours)
\end{tabular} & $\begin{array}{l}\text { Range } \\
\text { Median } \\
\text { IQR }\end{array}$ & \multicolumn{2}{|c|}{$\begin{array}{l}1-24 \\
4 \\
2-6\end{array}$} & \multicolumn{2}{|c|}{$\begin{array}{l}1.5-20 \\
5 \\
4-10\end{array}$} & \multicolumn{2}{|c|}{$\begin{array}{l}1-10 \\
2 \\
1-6.5\end{array}$} & \multicolumn{2}{|c|}{$\begin{array}{l}1-24 \\
4 \\
2-8\end{array}$} & $6.149^{c}$ & $0.051 *$ \\
\hline
\end{tabular}

a: One way ANOVA - b: Fisher-Freeman-Halton exact test - c: Kruskal-Wallis test - * significant at p $\leq$ 0.05 - IQR: Interquartile range

Table (4): Comparison between groups of RBS status as regards clinical data and outcomes $(\mathrm{N}=90)$

\begin{tabular}{|c|c|c|c|c|c|c|c|c|c|c|c|}
\hline & \multicolumn{2}{|c|}{ Euglycemia } & \multicolumn{2}{|c|}{ Hyperglycemia } & \multicolumn{2}{|c|}{ Hypoglycemia } & \multicolumn{2}{|c|}{ Total } & \multirow{2}{*}{$\begin{array}{c}\text { Test } \\
\text { statistic }\end{array}$} & \multirow[t]{2}{*}{$\mathrm{P}$} \\
\hline & & $\mathrm{N}$ & $\%$ & $\mathrm{~N}$ & $\%$ & $\mathrm{~N}$ & $\%$ & $\mathrm{~N}$ & $\%$ & & \\
\hline \multirow{3}{*}{$\begin{array}{l}\text { Severity of } \\
\text { toxicity }\end{array}$} & Mild & 26 & 89.7 & 2 & 6.9 & 1 & 3.4 & 29 & 100 & \multirow[t]{3}{*}{$16.781^{b}$} & \multirow[t]{3}{*}{$0.001 *$} \\
\hline & Moderate & 19 & 54.3 & 11 & 31.4 & 5 & 14.3 & 35 & 100 & & \\
\hline & Severe & 11 & 42.3 & 13 & 50 & 2 & 7.7 & 26 & 100 & & \\
\hline ChE (U/L) & $\begin{array}{l}\text { Range } \\
\text { Median } \\
\text { IQR }\end{array}$ & \multicolumn{2}{|c|}{$\begin{array}{c}89-11485 \\
2499 \\
1347-3500\end{array}$} & \multicolumn{2}{|c|}{$\begin{array}{c}451-11169 \\
1186.5 \\
945-2760\end{array}$} & \multicolumn{2}{|c|}{$\begin{array}{c}2600-3930 \\
3334.5 \\
2767-3815\end{array}$} & \multicolumn{2}{|c|}{$\begin{array}{c}89-11485 \\
2411 \\
1161-3480\end{array}$} & $10.580^{\mathrm{a}}$ & $\begin{array}{l}0.005^{*} \\
\text { p1 }=0.057 \\
\text { p2 }=0.244 \\
\text { p3 }=0.008^{*}\end{array}$ \\
\hline $\begin{array}{l}\text { Atropine } \\
\text { (ampule) }\end{array}$ & $\begin{array}{l}\text { Range } \\
\text { Median } \\
\text { IQR }\end{array}$ & \multicolumn{2}{|c|}{$\begin{array}{c}2-79 \\
10 \\
5-13\end{array}$} & \multicolumn{2}{|c|}{$\begin{array}{c}1-88 \\
7.5 \\
5-13 \\
\end{array}$} & \multicolumn{2}{|c|}{$\begin{array}{c}3-12 \\
7 \\
4-10\end{array}$} & \multicolumn{2}{|c|}{$\begin{array}{c}1-88 \\
10 \\
5-13\end{array}$} & $1.855^{\mathrm{a}}$ & 0.396 \\
\hline $\begin{array}{l}\text { Toxogonin } \\
\text { (ampule) }\end{array}$ & $\begin{array}{l}\text { Range } \\
\text { Median } \\
\text { IQR }\end{array}$ & \multicolumn{2}{|c|}{$\begin{array}{c}4-11 \\
4 \\
4-8\end{array}$} & \multicolumn{2}{|c|}{$\begin{array}{c}1-28 \\
4 \\
4-7\end{array}$} & \multicolumn{2}{|c|}{$\begin{array}{c}4-4 \\
4 \\
4-4\end{array}$} & \multicolumn{2}{|c|}{$\begin{array}{c}1-28 \\
4 \\
4-7\end{array}$} & $1.185^{\mathrm{a}}$ & 0.553 \\
\hline $\begin{array}{l}\text { Hospital } \\
\text { Stay (days) }\end{array}$ & $\begin{array}{l}\text { Range } \\
\text { Median } \\
\text { IQR }\end{array}$ & \multicolumn{2}{|c|}{$\begin{array}{c}0.5-6 \\
2.5 \\
2-3 \\
\end{array}$} & \multicolumn{2}{|c|}{$\begin{array}{c}0.3-10 \\
2 \\
1-4\end{array}$} & \multicolumn{2}{|c|}{$\begin{array}{c}1-3 \\
2 \\
2-2\end{array}$} & \multicolumn{2}{|c|}{$\begin{array}{c}0.25-10 \\
2 \\
2-3\end{array}$} & $1.957^{\mathrm{a}}$ & 0.376 \\
\hline \multirow[t]{2}{*}{ Tube } & No & 52 & $66.7 \%$ & 18 & $23.1 \%$ & 8 & $10.3 \%$ & 78 & $100 \%$ & \multirow[t]{2}{*}{$8.114^{\mathbf{b}}$} & \multirow[t]{2}{*}{$0.016^{*}$} \\
\hline & Yes & 4 & $33.3 \%$ & 8 & $66.7 \%$ & 0 & $0 \%$ & 12 & $100 \%$ & & \\
\hline \multirow[t]{2}{*}{ Ventilation } & No & 54 & $66.7 \%$ & 19 & $23.5 \%$ & 8 & $9.9 \%$ & 81 & $100 \%$ & \multirow[t]{2}{*}{$9.371^{\mathbf{b}}$} & \multirow[t]{2}{*}{$0.006^{*}$} \\
\hline & Yes & 2 & $22.2 \%$ & 7 & $77.8 \%$ & 0 & $0 \%$ & 9 & $100 \%$ & & \\
\hline \multirow[t]{2}{*}{ Mortality } & Survived & 54 & $67.5 \%$ & 18 & $22.5 \%$ & 8 & $10 \%$ & 80 & $100 \%$ & \multirow[t]{2}{*}{$11.639^{b}$} & \multirow[t]{2}{*}{$0.002 *$} \\
\hline & $\begin{array}{l}\text { Non- } \\
\text { survivor }\end{array}$ & 2 & $20 \%$ & 8 & $80.0 \%$ & 0 & $0.0 \%$ & 10 & $100 \%$ & & \\
\hline
\end{tabular}

N: number a: Kruskal-Wallis test - b: Fisher-Freeman-Halton exact test - * significant at $p \leq 0.05$ - IQR: 


\section{DISCUSSION}

Acute organophosphorus pesticide poisoning is a serious clinical problem in many countries with high mortality. The present study was designed to evaluate the effectiveness of RBS at the time of admission as a predictor for the outcomes of organophosphorus poisoned patients. In order to achieve this target, sociodemographic, toxicological, clinical data, and outcomes were analyzed against RBS findings in acute organophosphorus poisoned patients.

The results of sociodemographic characteristics, toxicological data, and clinical findings obtained in this study were comparable to results gathered from different poison control centers in Egypt and across the developing world (Panda et al., 2015; Abd El al et al., 2016; Elagamy \& Gabr, 2019 and Reddy et al., 2020).

Anticholinesterase-induced hyperglycemia has been explained by excess ACTH and catecholamine release after continuous cholinergic stimulation (Sudhir et al., 2013). According to Xiao et al. (2017), increased glycogen breakdown together with pancreatitis could be contributing factors of anticholinesterase-induced hyperglycemia.

Based on these reports, registering 26 hyperglycemic patients in the current study is reasonable. Furthermore, a significant positive correlation between RBS and delay time before hospital admission was recorded. A result that is totally in agreement with Sudhir et al. (2013), who proposed the stress of delayed treatment as a contributor to adrenaline gush and associated hyperglycemia.

A significant positive correlation between hyperglycemia and severity of poisoning was recorded in the present study. This finding was supported by Panda et al. (2015) and Raveendra et al. (2020), who reported a severe grade of poisoning in hyperglycemic patients. In addition, the grade of poisoning was found to be exaggerated by hyperglycemia and vice versa in both animal (Liu et al., 2007) and human studies (Raghapriya et al., 2018).

Such a positive correlation could be explained by the over-stimulation of nicotine receptors present on sympathetic ganglia leading to excess release of catecholamines from adrenal medulla. Moreover, severe cholinergic stimulation could increase ACTH release from the anterior pituitary. In addition, increased glycogenolysis and gluconeogenesis also contribute to this increase (Sudhir et al., 2013 and Panda et al., 2015).

Since depression of serum cholinesterase level is directly correlating with severity of organophosphorus poisoning (Elagamy \& Gabr, 2019), and the current study revealed a significant positive correlation between severity of organophosphorus poisoning and RBS of patients. It was expected to find a significant negative correlation between serum cholinesterase level and RBS in the present study. This finding agreed with Rao \& Raju (2016) and Raveendra et al. (2020), who recorded that hyperglycemia on admission directly correlates with depression of serum cholinesterase levels in organophosphorus poisoned patients.

In the present study, atropine \& toxogonin doses and duration of hospital stay registered no significant association with RBS. This finding was contradictory to Panda et al. (2015) and Raveendra et al. (2020), who reported a significant positive association between RBS of acute organophosphorus poisoned patients and the total dosage of atropine, toxogonin, and duration of hospital stay. Such inconsistency of result could be attributed to the difference in the number of severe cases in each study, along with variations in atropine \& toxogonin doses in treatment protocols among poison control centers.

There was a significant association between RBS and both mortality and need for mechanical ventilation $(80 \%$ and $77.8 \%$ of mortalities and ventilated patients respectively were hyperglycemic) in the present study. This result is in 
accordance with Raghapriya et al. (2018) and Raveendra et al. (2020). This could be explained considering the significant positive correlation between hyperglycemia and the severity of poisoning recorded in the present study.

\section{CONCLUSION}

It could be concluded that random blood sugar on admission in acute organophosphorus poisoned patients is a simple, cheap, and reliable marker that may help to predict the clinical severity and outcomes. To the best of the authors' recent knowledge, the current study is the first to investigate RBS as a predictor of mortality and the need for ventilation in acute organophosphate poisoned patients in Egypt.

\section{RECOMMENDATION}

Further research on larger scales are needed to investigate the glycemic state as a predictor for cholinergic toxicity outcomes.

\section{REFERENCES}

Abd El AL, A. H., Fawzi, M. M., Alkhafif, M. A. And El-Zemaity, M. E. (2016): Epidemiological Study of Organophosphorus Compounds Insecticides Types Related To Acutely Intoxicated Patients Presented To Poison Control Center (PCC-ASU)Egypt, IOSR Journal of Environmental Science, To xicology and Food Technology (IOSRJESTFT), 10:2319-2399.

Afify, T., El-Barrany, U., Elshikhiby, H., Adly, M. and Fathy, S. (2016a): Effect of intravenous magnesium sulphate on atropine and oxime usage in acute organophosphate toxicity, The Egyptian Journal of Forensic Sciences and Applied Toxicology, 16(1)17-22.

Afify, T., El-Barrany, U., Elshikhiby, H., Adly, M. and Fathy, S. (2016b): effect of intravenous magnesium sulphate on mortality rate in acute organophosphate toxicity, The
Egyptian Journal of Forensic Sciences and Applied Toxicology, 16(1)11-15.

Blawen, D., Poppe, D. H. and Trischler, W. A. (1983): Serum acetylcholinesterase assay. J. Clin. Chem. Biochem, 21:381-386.

Dungdung, A., Kumar, A., Kumar, B., Preetam, M., Tara, R. K. and Saba, M. K. (2020): Correlation and prognostic significance of serum amylase, serum lipase, and plasma cholinesterase in acute organophosphorus poisoning, Journal of family medicine and primary care, 9(4):1873-1877.

Elagamy, S. E. and Gabr, H. M. (2019): Predictors of the need for Intensive Care Unit admission in acute organophosphorus poisoning: One year prospective study, The Egyptian Journal of Forensic Sciences and Applied Toxicology, 19(4):1-9.

El-Ebiary, A., Soliman, M. and Hafez, E. (2016): Electrocardiographic Findings and Prognostic Value of Long QTc Interval in Acute Organophosphate Insecticide Poisoning, Ain Shams Journal of Forensic Medicine and Clinical Toxicology, 26(1):1-6.

Geetha Rani, A., Bhuvaneshwaran, B. and Idhaya, I. (2020): Incidence and pattern of poisoning cases admitted in a tertiary care center, National Journal of Physiology, Pharmacy and Pharmacology, 10:309-312.

Kende, M. and Bottger, R. (1967): Kiln. Wschr. 45: 325-327.

Kharel, H., Pokhrel, N. B., Ghimire, R. and Kharel, Z. (2020): The Efficacy of pralidoxime in the treatment of organophosphate poisoning in humans: A Systematic Review and Meta-analysis of Randomized Trials. Cureus; 12 (3):1-16.

Kurtoglu, S. (2019): Acute and Long-term Effects of Organophosphate Poisoning. Erciyes Medical Journal; 41(1):3-5. 
Liu, J., Gupta, R. C., Goad, J. T., Karanth, S. and Pope, C. (2007): Modulation of parathion toxicity by glucose feeding: Is nitric oxide involved? Toxicology and Applied Pharmacology, 219(2):106-113.

Minton, N. A. and Murray, V. S. G. (1988): A Review of Organophosphate Poisoning, Medical Toxicology and Adverse Drug Experience, 3(5):350375.

Oliveira, C., Bagetta, D., Cagide, F., Teixeira, J., Amorim, R., Silva, T., Garrido, J., et al. (2019): Benzoic acid-derived nitrones: A new class of potential acetylcholinesterase inhibitors and neuroprotective agents, European Journal of Medicinal Chemistry, 174:116-129.

Panda, S., Rachita, N. R., Mangaraj, M., Rathod, P. K. and Mishra, P. K. (2016): Glycemic Status in Organophosphorus Poisoning, Journal of Nepal Health Research Council, 13(31):214-219.

Raghapriya, R., Dosi, R. and Parmar, A. (2018): Glycemic Status at the Time of Presentation in Acute Organophosphorous Poisoning and its Correlation with Severity and Clinical Outcome, The Journal of the Association of Physicians of India, 66:18-22.

Ramchander Rao, D. and Raju, G. (2016): Random blood sugar levels and pseudocholinesterase levels their relevance in organophosphorus compound poisoning, International Journal of Community Medicine and Public Health, 3(10):2757-2761.

Raveendra, K. R., Chandana, V. and Kodur, S. (2020): A prospective study to assess glycemic status as a possible prognostic marker in non- diabetic acute organophosphate poisoning patients', International Journal of Advances in Medicine, 7 (3):464-469.

Reddy, B. S., Skaria, T. G., Polepalli, S., Vidyasagar, S., Rao, M., Kunhikatta, V., Nair, S. et al. (2020): Factors associated with outcomes in organophosphate and carbamate poisoning: a retrospective study, Toxicological Research, 36(3):257-266.

Schober, P., Boer, C. and Schwarte, L. A. (2018): Correlation Coefficients: Appropriate Use and Interpretation, Anesthesia \& Analgesia, 126(5):17631768.

Sharp, P. (1972): Interference in glucose oxidase-peroxidase blood glucose methods, Clinica Chimica Acta, 40(1):115-120.

Sudhir, U., Chandrashekar, Pai. R., Sunil, H. S., Medha, Y. R. and Kempegowda, P. (2013): Glycemic changes in acute anticholinesterase insecticide poisoning. The West London Medical Journal; 5(1):27-33.

Trinder, P. (1969): Determination of Glucose in Blood Using Glucose Oxidase with an Alternative Oxygen Acceptor, Annals of Clinical Biochemistry, 6(1):24-27.

Tsai, J. R., Sheu, C. C., Cheng, M. H., Hung, J. Y., Wang, C. S., Chong, I. W., Huang, M. S. et al. (2007): Organophosphate Poisoning: 10 Years of Experience in Southern Taiwan, The Kaohsiung journal of medical sciences, 23:112-119.

Xiao, X., Clark, J. and Park, Y. (2017): Potential contribution of insecticide exposure and development of obesity and type 2 diabetes, Food and Chemical Toxicology, 105: 456-474. 


\section{مستوي السكر في الام كمتبئ للنتائج في مرضصى اللتسمم الحاد بمبيدات الآفات الفسفورية}

يعد التسمح الحاد بمبيدات الفوسفور العضوي من المشكلات الصحيه الخطيرة المنتشره في العديد

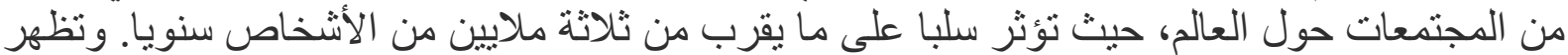

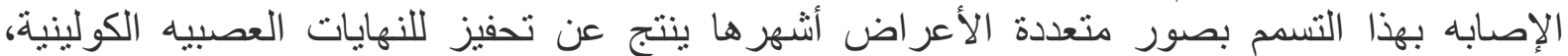

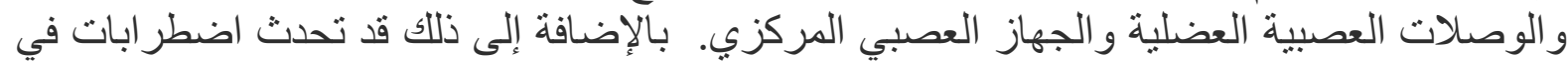

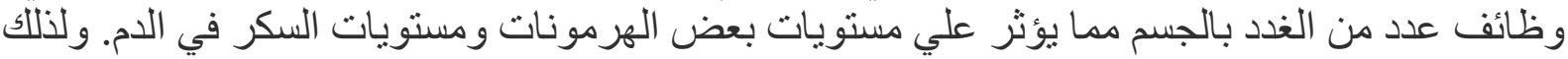
كان الهذف من الدراسة الحالية هو الكثف عن إمكانية إستخدام مستوي السكر في الدام (وقت دخول

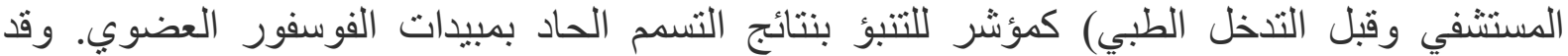

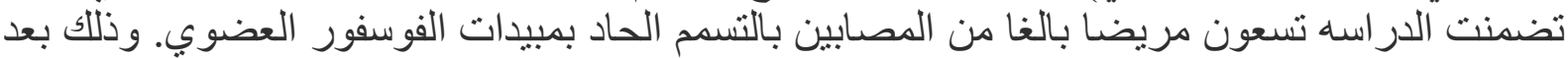

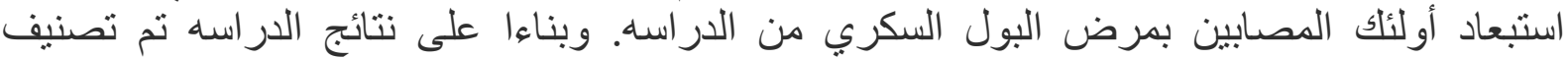

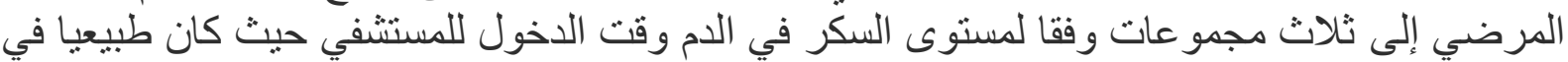

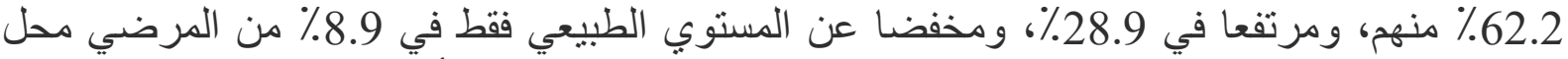

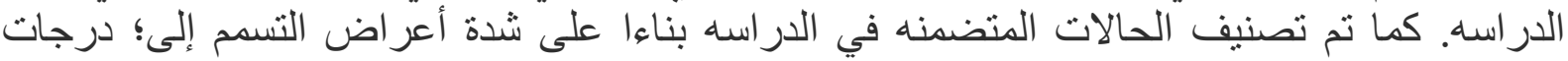
خفيفة (32.2\%) ومتوسطة (38.9\%) ومرتفعة (28.9\%) مع وجود ارتباط ذي دولالة إحصائية بين

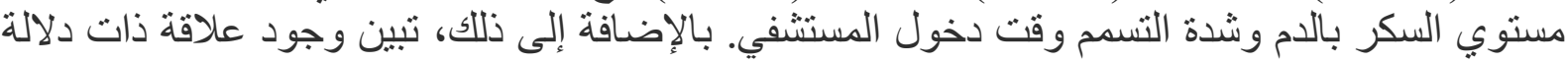

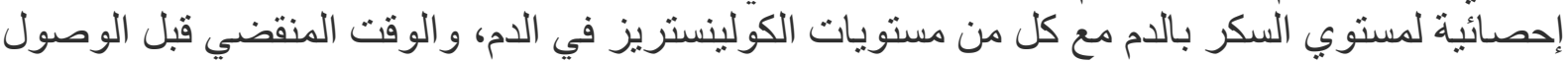

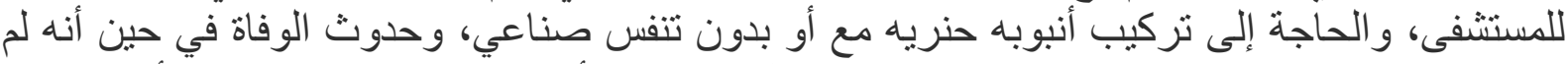

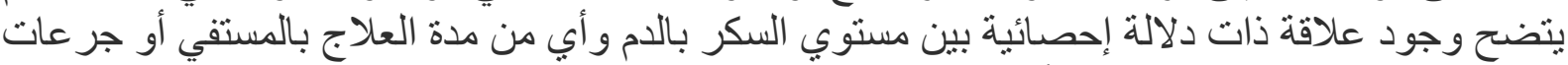
العلاجات الماده للتسم المستخدمه (أتروبين و تكسوجو دونين). 